\title{
IMPLEMENTASI SEBARAN INFORMASI PROFIL DESA PETUNG SEWU
}

\author{
Soetam Rizky Wicaksono ${ }^{1}$, Felik Sad Windu Wisnu Broto ${ }^{2}$, Paulus Lucky Tirma Irawan ${ }^{3}$ \\ ${ }_{1}^{1,2,3}$ Universitas Ma Chung Malang \\ email: soetam.rizky@machung.ac.id
}

\begin{abstract}
Information dissemination in village is an obligation which must be done from its local government to society. Demographic data and village profile should be written well to make people being able optimizing village market potential and beyond its environment. That phenomenon also happened in Petung Sewu Village, which is locate in Kecamatan Dau, Kabupaten Malang near by Universitas Ma Chung. This village approximately located $8 \mathrm{~km}$ from university. Thus, in this community service activity already done analyzing and data collection process until its accompaniment and installation of the system. Eventhough the result of aplication being built is far from perfect, however, all of the target from prior proposal already reached out.
\end{abstract}

Keywords: Information dissemination, Community Service, Petung Sewu

\begin{abstract}
Abstrak. Sebaran informasi di lingkup desa merupakan sebuah kewajiban yang harus dilakukan oleh pihak perangkat desa ke masyarakat. Sebaran data demografi dan profil desa seharusnya mampu menjadikan masyarakat yang akan membuka usaha dapat memahami pasar dari lingkungan sekitarnya. Fenomena tersebut juga terjadi di desa Petung Sewu kecamatan Dau, Kabupaten Malang. Desa Petung Sewu yang berlokasi kurang lebih hanya $8 \mathrm{~km}$ dari Universitas Ma Chung. Karenanya dalam aktifitas ini dilakukan analisis dan pengumpulan data untuk sistem informasi profil desa, dan pendampingan berupa instalasi hingga pelatihan setelah sistem selesai dibuat. Meski aplikasi belum mendekati ambang sempurna, namun target dari pelaksanaan aktifitas pengabdian telah tercapai sesuai dengan proposal yang ditetapkan
\end{abstract}

Kata kunci : Sebaran Informasi, Pengabdian Masyarakat, Petung Sewu

\section{PENDAHULUAN}

Sebaran informasi di lingkup desa merupakan sebuah kewajiban yang harus dilakukan oleh pihak perangkat desa ke masyarakat. Berdasarkan UU Desa no. 16 tahun 2014, pasal 26 ayat 4, bahwa Kepala Desa wajib memberikan informasi kepada masyarakat desa (Dewan Perwakilan Rakyat, 2014). Sehingga sebaran informasi desa bukan lagi sebuah gengsi dari desa, tapi merupakan amanah undangundang yang wajib dilaksanakan.

Terlebih sebaran informasi tentang profil desa serta data dasar demografi seringkali tidak diketahui dan dipahami oleh warga dari desa tersebut. Jika terdapat data tersebut, maka data hanya berupa tempelan di papan pengumuman yang berada di kantor kepala desa atau kelurahan, yang bahkan untuk melihatnya membutuhkan usaha ekstra dikarenakan pada umumnya memiliki tulisan yang cukup kecil sehingga sulit untuk dibaca.

Hal tersebut kerap menjadikan warga menjadi lemah dalam memahami informasi desa yang sesungguhnya dapat menjadi senjata utama dalam pengembangan desa itu sendiri. Sebagai contoh, sebaran data demografi dan profil desa seharusnya mampu menjadikan masyarakat yang akan membuka usaha dapat memahami pasar dari lingkungan sekitarnya.

Padahal di era revolusi industri 4.0, keterbukaan informasi merupakan salah satu hal penting dan sangat mudah dilakukan. Perkembangan teknologi internet menjadikan masyarakat desa seharusnya lebih mudah mendapat akses informasi desa yang dibutuhkan. Terlebih penetrasi internet di Indonesia hingga tahun 2019, telah mencapai setidaknya 56\% (Nistanto, 2019). Sehingga hal ini menunjukkan bahwa kebutuhan sebaran informasi berbasis 
internet dapat diimplementasikan dengan mudah dan berdaya guna. Di sisi lain, penetrasi internet di Indonesia saat ini didominasi oleh penggunaan smartphone yang mencapai angka hingga di atas 50\% (Nistanto, 2019) . Hal ini menjadikan alasan kuat agar sebaran informasi melalui internet nantinya dapat lebih efektif jika dipurwarupakan menjadi aplikasi berbasis mobile. Karenanya pihak desa seharusnya memiliki perangkat sebaran informasi berbasis mobile di lingkup wilayahya.

Fenomena tersebut juga terjadi di desa Petung Sewu kecamatan Dau, Kabupaten Malang. Desa Petung Sewu yang berlokasi kurang lebih hanya $8 \mathrm{~km}$ dari Universitas Ma Chung memiliki banyak sejarah kedekatan dengan pihak universitas, karena telah kerap menjadi sasaran aktifitas pengabdian masyarakat bagi pihak civitas akademika.Sehingga diperlukan adanya sebaran informasi profil desa dalam bentuk yang praktis dan dapat diakses secara luas dan mudah oleh masyarakat.

Di dalam aktifitas pengabdian masyarakat ini, diambil lokasi Desa Petung Sewu kecamatan Dau yang terletak di kabupaten Malang dengan jumlah penduduk kurang lebih 3000 jiwa, serta pemetaan kesuburan tanah yakni sangat subur sebesar $56 \mathrm{Ha}$, subur sebesar $97 \mathrm{Ha}$, sedang 112 Ha dan kriteria tidak subur / kritis 9 Ha. memiliki potensi sumber daya alam yang sangat potensial. Sehingga memiliki banyak informasi yang seharusnya disebarkan secara masif baik ke penduduk maupun ke khalayak umum. yang layak untuk pembuatan profil desa (Dörr, Walther, \& Eymann, 2013). Sebab kualitas Di dalam pelaksanaan pengabdian ini, langkah yang ditempuh oleh tim pendamping dengan dukungan dari sebagai mitra dapat dijabarkan sebagai berikut: (1) langkah pertama adalah dengan melakukan proses brainstorming dengan pihak perangkat desa sekaligus mengumpulkan data demografi, (2) langkah kedua adalah melakukan proses analisis awal untuk pembuatan sistem informasi dan melakukan pengumpulan data profil desa, (3) langkah berikutnya adalah melakukan unggah aplikasi sistem informasi ke play store untuk kemudian menjadi sebaran informasi profil desa (4) langkah keempat adalah melakukan pelatihan dan pendampingan pemanfaatan aplikasi, dan (5) langkah terakhir adalah melakukan evaluasi akhir sekaligus pelaporan dan penerbitan karya ilmiah ke jurnal yang telah ditargetkan sebelumnya.

\section{METODE PELAKSANAAN}

Berdasarkan analisis dan permasalahan yang telah dijabarkan sebelumnya, maka dapat ditemukan bahwa solusi dari permasalahan adalah dengan dua jenis aktifitas utama, yakni: (1) melakukan analisis dan pengumpulan data untuk sistem informasi profil desa, dan (2) melakukan pendampingan berupa instalasi hingga pelatihan setelah sistem selesai dibuat.

Proses analisis dan pengumpulan data dilakukan dengan cara interview dan juga proses pengumpulan data. Hal ini diupayakan agar informasi yang diperoleh dapat memiliki kualitas

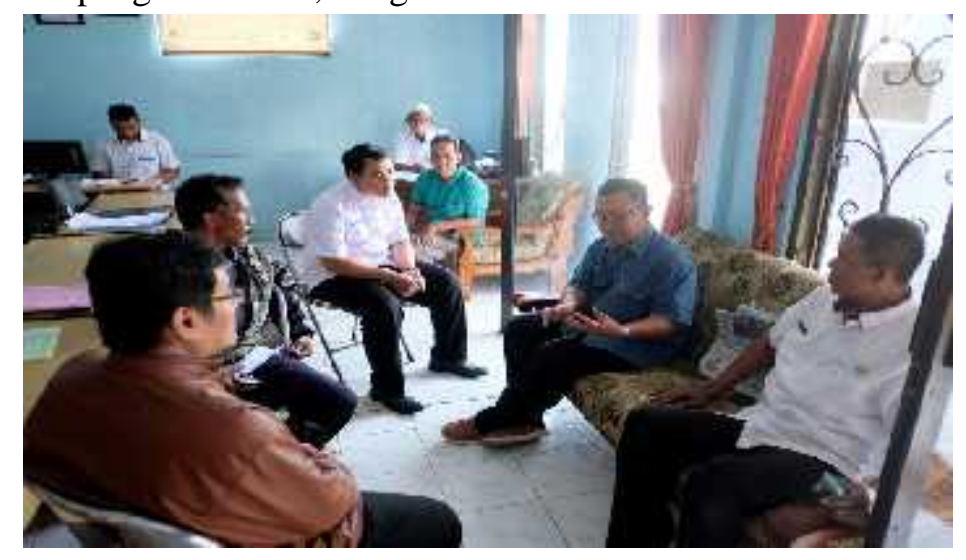

Gambar 1. Aktifitas Brainstorming 


\section{HASIL DAN PEMBAHASAN}

Berdasarkan metode pelaksanaan yang telah dijabarkan sebelumnya, maka hasil dari aktifitas pengabdian masyarakat yang telah dilakukan telah selesai dilaksanakan. Sedangkan uraian dari aktifitas tersebut adalah: (1) proses brainstorming yang dilakukan oleh tim dilakukan sebanyak empat kali dan terjadwal sejak bulan Januari hingga Maret 2019. Proses tersebut diawali dengan pertemuan bersama perangkat desa untuk melakukan pendekatan awal dan kemudian dilanjutkan dengan pertemuan bersama kepala desa untuk penegasan maksud dan tujuan yang ingin dicapai. Hingga pada akhir langkah ini bisa didapat persetujuan dari pihak kepala desa beserta perangkatnyaLangkah yang kedua, (2) adalah proses pengumpulan data untuk pembuatan sebaran informasi profil desa. Pada tahapan ini dilakukan proses pengumpulan data dari pihak perangkat desa yang kemudian diaggregasikan ke dalam aplikasi mobile. Proses aggregasi data ini dilakukan dengan memperhitungkan faktor demografi dan geografi dari desa Petung Sewu. Sedangkan data yang berasal dari aspek budaya dan politik, hukum serta keamanan belum dapat diikutsertakan dikarenakan kurangnya data dari pihak perangkat desa.

Langkah ketiga, (3) yang melakukan proses unggah aplikasi sistem informasi sebaran profil ke play store. Pada proses ini masih belum bisa diasumsikan selesai dikarenakan revisi unggah aplikasi masih terjadi. Revisi tersebut dikarenakan sifat dinamis data serta ketidakrapian perangkat desa dalam melakukan proses aggregasi data. Namun demikian, proses unggah ini diperkirakan dapat berlangsung singkat dengan syarat aggregasi data telah dianggap final. Meski langkah ketiga belum sepenuhnya selesai tetapi aplikasi yang direncanakan dapat diunggah telah mencapai tahapan final. Sehingga sebaran informasi untuk profil desa yang diharapkan telah tercapai dengan baik.
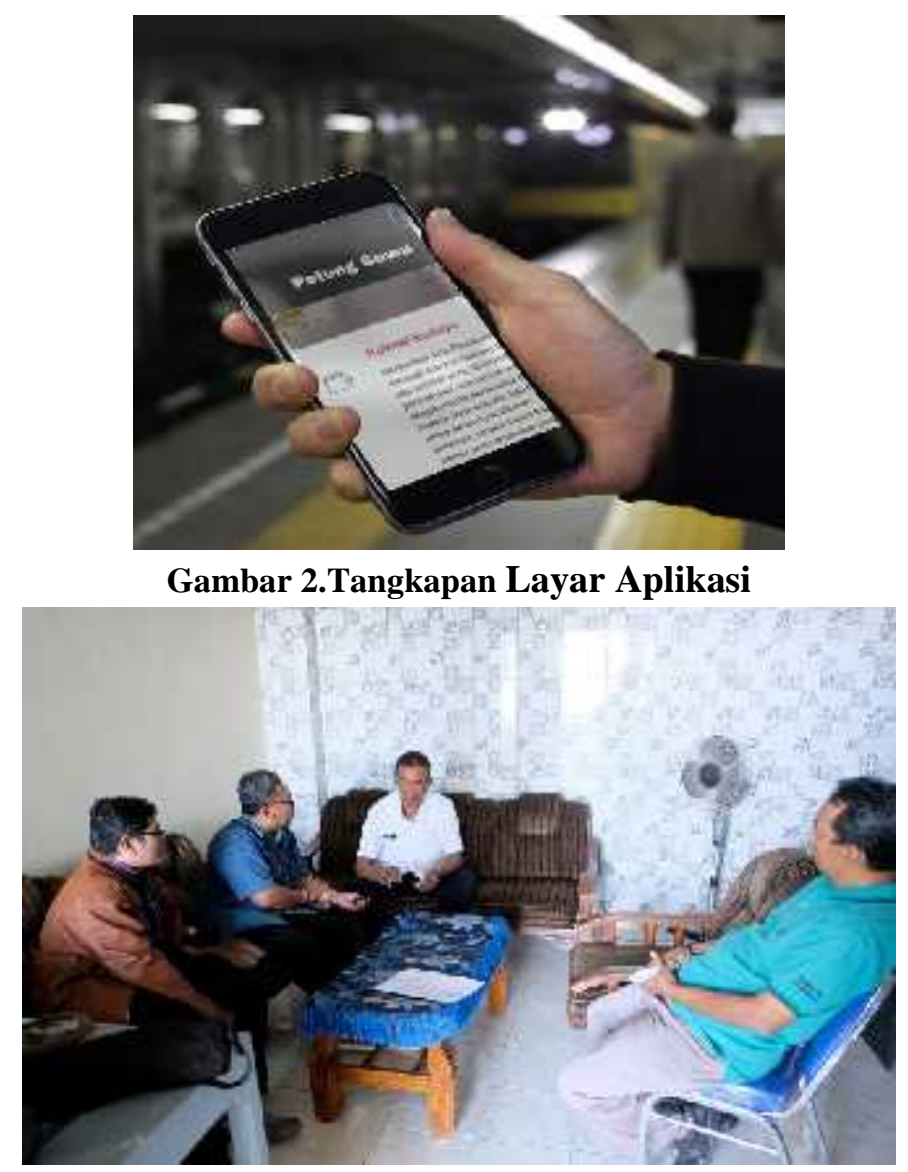

Gambar 3.Proses Pendampingan Kepala Desa 
Langkah keempat dan kelima, yakni pendampingan dan pelatihan untuk perangkat desa, dilakukan pada pertengahan tahun 2019. Pendampingan tersebut berlangsung singkat, dikarenakan aplikasi yang dihasilkan merupakan aplikasi berbasis mobile yang sangat mudah untuk dioperasikan. Sedangkan informasi yang terdapat didalamnya telah dilakukan entri terlebih dulu oleh tim pengabdian masyarakat.

Sedangkan langkah kelima yakni publikasi ke jurnal, telah dilakukan dengan adanya penulisan jurnal ini. Dalam penulisan jurnal ini, tetap digunakan kaidah ilmiah dengan mempertimbangkan kajian teori serta product life cycle dari aplikasi yang dihasilkan. Sebab aplikasi yang dihasilkan dalam aktifitas pengabdian ini masih belum sempurna dan membutuhkan dana serta usaha yang lebih untuk mencapai tahapan growth, setelah tahapan birth and research selesai dilakukan (Shahmarichatghieh, Tolonen, \& Haapasalo, 2015).

\section{SIMPULAN DAN SARAN}

Hasil dari aktifitas pengabdian masyarakat yang telah dilakukan hingga jurnal ini ditulis dapat disimpulkan telah mencapai target yang telah ditetapkan pada saat proposal awal dilaksanakan. Namun demikian beberapa fitur masih jauh dari batasan sempurna, khususnya untuk aplikasi yang dibuat. Sehingga direncanakan bahwa aktifitas pengabdian masyarakat ini dapat dilanjutkan untuk kegiatan di tahun anggaran berikutnya yang nanti akan dimulai pada bulan Agustus 2019.

Hasil dari aplikasi yang dihasilkan masih dalam tahapan birth and research yang merupakan tahapan awal dari sebuah product life cycle secara umum. Untuk mencapai tahapan berikutnya, yakni tahapan growth diperlukan analisis berdasarkan hasil evaluasi kegiatan saat ini. Sehingga masih diperlukan pula pendekatan secara informal terhadap pihak perangkat desa Petung Sewu untuk dapat memberikan informasi secara lebih detail agar sebaran informasi yang dihasilkan bisa menjadi lebih akurat.

\section{DAFTAR PUSTAKA}

Dewan Perwakilan Rakyat. Undang Undang Desa no. 16 (2014). Retrieved from http://www.dpr.go.id/doksileg/proses2/RJ2 -20171106-094054-7086.pdf

Dörr, S., Walther, S., \& Eymann, T. (2013). Information Systems Success - A Quantitative Literature Review and Comparison. Wirtschaftsinformatik, (March), 1813-1827.

Nistanto, R. K. (2019, February 4). Riset: Penetrasi Internet Indonesia Naik Jadi 56 Persen. Kompas. Retrieved from https://tekno.kompas.com/read/2019/02/04 /11420097/riset-penetrasi-internetindonesia-naik-jadi-56-persen

Shahmarichatghieh, M., Tolonen, A., \& Haapasalo, H. (2015). Product Life Cycle, Technology Life Cycle and Market Life Cycle; Similarities, Differences and Applications. In Management, Knowledge and Learning Joint International Conference 2015 (pp. 1143-1151). 